\title{
Who Needs Entrepreneurial Role Models? Driving Forces of Students' Cyber-Entrepreneurial Career Intention
}

\author{
Shu-Hsuan Chang ${ }^{1}$, Chih-Lien Wang ${ }^{2 *}$, Jing-Chuan Lee ${ }^{2}$, Li-Chih Yu ${ }^{3}$ \\ ${ }^{1}$ Department of Industrial Education \& Technology, National Changhua University of Education, Changhua, TAIWAN \\ ${ }^{2}$ Graduate Institute of Educational Leadership and Evaluation, Southern Taiwan University of Science and Technology, Tainan, \\ TAIWAN \\ ${ }^{3}$ E-Learning Center, National Changhua University of Education, Changhua, TAIWAN
}

Received 10 November 2017 - Revised 12 April 2018 - Accepted 30 April 2018

\begin{abstract}
Cyber-entrepreneurship has become an important topic of debate in academia primarily because of an increasingly competitive nature of E-commerce industry and internet. Since cyber-entrepreneurial career-decision encompasses higher degree of personal risks and commitments among those aspiring to become 'cyberentrepreneurs', there is need for in-depth understanding on the driving factors that influencing Cyber-entrepreneurial intentions. By integrating the concepts of social cognitive theory and goal-setting theory, the current research aims to explore the effects of Cyber-entrepreneurial self-efficacy (CESE) and goal commitment (GC) on Cyber-entrepreneurial intentions (CEIs) in the context of undergraduate entrepreneurship education, and inquires whether the presence of entrepreneurial role models (ERMs) has any effect on the CEls among undergraduates. Structural equation modeling and multi-group analysis were used to analyze the data collected from 279 undergraduate students from several universities in Taiwan-among which 146 were with entrepreneurial role models and 143 were without. The results showed that GC has a partial mediation effect between CESE and CEI only in the cases of students without ERMs. Multi-sample SEM revealed a significant difference between the effects of CESE on CEI in students with and without ERMs. These findings may have important theoretical and practical implications to students undertaking entrepreneurship degrees and those making leap-decisions to enter the cyber-entrepreneurial field.
\end{abstract}

Keywords: career decisions, cyber entrepreneurial intentions, cyber entrepreneurial self-efficacy, entrepreneurship education, goal commitment

\section{INTRODUCTION}

The advancement of information and communication technology has led to a boom in e-commerce and created an alternative to traditional entrepreneurship. Today, e-commerce accounts for $89.7 \%$ of the global annual sales amount, and is mainly concentrated in three regional markets - Asia-Pacific, North America, and Western Europe. Comparatively, Asia-Pacific demonstrates the strongest potential growth with the expected compound annual growth rate increase to $15.8 \%$ in 2014 (eMarketer, 2014). The emergence of mobile technology in recent years further launched cyber entrepreneurship into an innovative, dynamic and cost-effective alternative to the traditional model (Matlay \& Westhead, 2007; Wang et al, 2016). In light of these changes, the Taiwanese government has proposed relevant policies to promote the growth and development of the e-commerce industry and entrepreneurship; cyberentrepreneurship-related courses, therefore, have also flourished in Taiwanese universities (Ministry of Economic Affairs, 2016).

(C) 2018 by the authors; licensee Modestum Ltd., UK. This article is an open access article distributed under the terms and conditions of the Creative Commons Attribution License (http://creativecommons.org/licenses/by/4.0/).

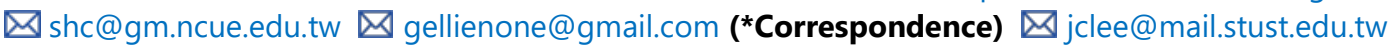




\section{Contribution of this paper to the literature}

- Integrating the concepts of social cognitive theory and goal-setting theory, the current research explored the effects of Cyber-entrepreneurial self-efficacy (CESE) and goal commitment (GC) on Cyber-entrepreneurial intentions (CEIs) in the context of undergraduate entrepreneurship education, and further investigated whether the presence of entrepreneurial role models (ERMs) has any effect on the CEIs of students.

- Research results showed that students' CESE has positive effect on their GC and CEIs individually, and their GC has a positive effect on their CEIs. However, GC only has a partial mediation effect between CESE and CEIs in no presence of entrepreneurial role models (NERMs) but not in presence of entrepreneurial role models (PERMs).

- This research concluded that cyber-entrepreneurship educators and practitioners will be able have a better understanding of the students' CESE through their levels of GC, and come up with better methods or designs for the entrepreneurial curricula that will further promote students' CEIs.

Creativity, innovation, and entrepreneurship have been integrated into one widely-discussed hot topic in higher education (Edwards-Schachter et al, 2015; Lubart, 2008). These concepts increasingly recognized as the engines that foster an entrepreneurial culture (OECD, 2011). Creative thinking aims to explore and formulate the originality, take risks and tolerate ambiguity to bring the value of creative act, product, or idea (Anderson, Thier, \& Pitts, 2017). Creative skills enable students to discover ideas and opportunities conducive to innovation; entrepreneurship programs and courses provide the context and materials that allow students to learn and apply skills and behaviors needed to create value in entrepreneurial firms (Gundry, Ofstein, \& Kickul, 2014). The incorporation of these topics as part of the 'core competency' of educational programs has become a central theme in the face of today's turbulent markets and the complex demands by the rapid technological and societal changes (Gattie, Kellam, Schramski, \& Walther, 2011; Vanevenhoven, 2013).

Interdisciplinary learning is an important part of talent cultivation. Entrepreneurship education aims to offer students alternative career choices by fostering their entrepreneurial intentions and skills (Huang, 2017; Jiang, Xiong, \& Cao, 2017; Sánchez, 2011). Furthermore, entrepreneurial courses further enabled the students to balance theory and practice through the principle of learning by doing to choose to start their own business (Wu, Kuo, \& She, 2013).

With the encouragement of the Taiwanese government, innovation and entrepreneurship platforms have been established one after another by colleges and universities, and entrepreneurship courses increased sevenfold over the past ten years (Ministry of Education, 2016). For example, TiC100, founded in 1999 by Advantech, provided the entrepreneurial events by means of entrepreneurial contests, innovative business model competitions and internet of thing (IoT) application development contests to cultivate thousands of university students' into entrepreneurship fields (TiC 100, 2018). Furthermore, to assist young people to start-up their own business, the Ministry of Education Youth Development Department (2012) promulgates “...cultivating quality manpower and promoting employment programs" to provide venture fund and incubators for university graduates who showed and demonstrate entrepreneurial intentions and competencies.

In spite of government efforts, less than $25.9 \%$ (ranked $53^{\text {rd }}$ among the 54 economies) of the Taiwanese adults believe they have entrepreneurial capabilities even though $71.1 \%\left(11^{\text {th }}\right)$ of them believe entrepreneurship to be a good career choice. Moreover, Taiwan ranked 22nd in the fear of failure during entrepreneurial process category (Global Entrepreneurship Research Association, 2018). One probable explanation is that the cost of entrepreneurial opportunities might be higher for the highly educated technicians and professionals, and that their risk of failure might be greater in entrepreneurship than in employment (Liu, Wen, \& Hsieh, 2011). This discrepancy between entrepreneurial intentions and behaviors highlights the importance of having educational programs and curricula designed to foster the development of entrepreneurship (Geldhof et al, 2014). Previous findings have already shown that participation in entrepreneurial courses has a positive effect on people's entrepreneurial potential and attitudes (Stokes \& Wilson, 2010). The investigation of the factors that influence CEIs and their causal relationships is therefore of paramount importance to entrepreneurship education.

Studies have found that the environmental and situational factors and opportunities can directly affect an individual's career (Callanan \& Zimmerman, 2016; Liñán \& Fayolle, 2015; Shepherd, Williams, \& Patzelt, 2015). The role of self-efficacy in occupational choice and preparation has been the focus of research on career choice and development in social cognitive theory (Betz \& Hackett, 1997; Lent, Brown, \& Hackett, 1994). This study helps to clarify the impact of self-efficacy on decision-making behaviors. However, several publications have claimed that the belief in one's capabilities not only has no determinative function, it can even be self-deprecating (Vancouver et al, 2002; Vancouver, Thompson, \& Williams, 2001). For their part, Bandura and Locke (2003) presented a large body of evidence that disproved such findings. Confronted with these contradictory results, further investigation 
is required to verify if CESE and other factors indeed affect cyber-entrepreneurial career decisions and if so, in what ways for potential/aspiring cyber entrepreneurs.

The goal-oriented behavior of entrepreneurs is becoming an area of great interest among researchers. Commitment is a force that binds an individual to a course of action and its associated target (Meyer, Becker, \& Van Dick, 2006). While self-efficacy may be a motivational or de-motivational force depending on a person's selfenhancing or self-deprecating beliefs (Bullough \& Renko, 2013), GC might be one of its determining factors (Callanan \& Zimmerman, 2016; Przepiorka, 2016). Goal-setting theory proposed four mechanisms through which goals affect performance: choice, effort, persistence, and strategies (Locke \& Latham, 2002). For entrepreneurs, the decision to start a company is the result of careful planning and deliberate action that entails great energy and commitment. Goal commitment is an individual's willing to accomplish his/her setting target (Locke, Shaw, Saari, \& Latham, 1981) and it will be influenced by self-efficacy (Locke \& Latham, 2002). Entrepreneurial educators could improve students' entrepreneurial self-efficacy by entrepreneurial role modeling or entrepreneurial models with whom the aspiring/wannabe entrepreneurs can identify (Bandura, 1997; Locke \& Latham, 2002; White \& Locke, 2000). Moreover, Callanan and Zimmerman (2016) suggested the application of a structured career management model to all phases of the entrepreneurial career decision-making process; and pointed out that the establishment of realistic goals can facilitate the development and implementation of career strategies. The present study seeks to integrate the concepts of social-cognitive theory and goal-setting theory in examining the relationships among CESE, GC, and CEI to effectively promote students' CEI in the context of undergraduate education.

Entrepreneurship education and entrepreneurial role models both have impacts on the entrepreneurial intentions of students in developing countries (Muofhe \& Du Toit, 2011). Muofhe and Du Toit (2011) observed that positive relationships exist between entrepreneurship education and entrepreneurial intentions, and entrepreneurial role models and entrepreneurial intentions. Some studies have also confirmed that the entrepreneurial competence of young adults is predictable by their entrepreneurial personality traits, the authoritative parenting style of their parents, and the presence of entrepreneurial role models in their lives (Obschonka, Silbereisen, \& Schmitt-Rodermund, 2011). Adult entrepreneurial mentors such as parents may be the key to the development of entrepreneurial intentions in young adults careers (Schmitt-Rodermund, 2004). In light of the above, we divided our samples into the categories of students who have the presence of entrepreneurial role models in their lives (PERMs) and students who do not have (NERMs) to compare and explore the differences between their CESEs, GCs, and CEIs. Here, ERMs refer to family member, teachers/professors, and/or friends.

\section{THEORETICAL FRAMEWORK AND HYPOTHESES}

\section{The Effect of Students' Cyber-Entrepreneurial Self-Efficacy (CESE) on their Cyber- Entrepreneurial Intentions (CEIs)}

The making of an entrepreneur is dependent on the contribution of multiple factors, e.g., personal attributes, background, experience and trait combinations (Arenius \& Minniti, 2005; Baron, 2004; Shane, Locke, \& Collins, 2003). One of such factors is entrepreneurial self-efficacy (ESE). It refers to a person's ability to believe that he/she can successfully achieve the tasks necessary for an entrepreneur (McGee, Peterson, Mueller, \& Sequeira, 2009). Commitment can be accompanied by different ways of thinking that plays a role in shaping behavior and may even lead to the persistence to a course of action, even in the face of conflicting motives or attitudes (Meyer \& Herscovitch, 2001). ESE has a high degree of influence over the entrepreneurial intention of and the extent of effort made by a potential entrepreneur; and it affects his/her willingness to withstand the changes and challenges they encounter during the entrepreneurial process in order to become a successful entrepreneur (Trevelyan, 2011).

ESE is an important antecedent and an effective predictor of entrepreneurial intentions (Barbosa, Gerhardt, \& Kickul, 2007; McGee et al., 2009). Empirical studies have confirmed its significant effect on students' entrepreneurial intentions (BarNir, Watson, \& Hutchins, 2011; Carr \& Sequeira, 2007; Kickul, Gundry, Barbosa, \& Whitcanack, 2009; Liñán, 2008; Piperopoulos \& Dimov, 2015; Sesen, 2013; Zhao, Seibert, \& Hills, 2005). Base on the above claims findings, we propose the following hypothesis.

H1: Students' CESE has a positive effect on their CEI. $(X \rightarrow Y, c)$

\section{The Effect of Students' Cyber-Entrepreneurial Self-Efficacy on their Goal Commitment}

An established goal is a driving force that makes people focus, take action, persist and persevere in tackling with increasingly difficult tasks until the desired outcome is achieved (De Clercq, Menzies, Diochon, \& Gasse, 2009). Self-efficacy, on the other hand, affects an individual's goal setting (Boyd \& Vozikis, 1994), and is proven to be an important factor conducive to the enhancement of goal commitment (Locke \& Latham, 2002). Empirical studies have shown that when an individual's self-efficacy is higher, their goal commitment becomes stronger as well (De 
Clercq et al., 2009; Locke, Frederick, Lee, \& Bobko, 1984; Wood \& Bandura, 1989; Wu, 2002). In light of that, the following hypothesis is proposed.

H2: Students' CESE has a positive effect on their GC. $(X \rightarrow M, a)$

\section{The Mediation of Goal Commitment}

An individual's self-efficacy and personal goals are both important factors that influence their behavior (Bandura, 1997). Strong commitment to the goal and strong intentions to achieve it are demonstrated when one can accurately anticipate that the result of achieving the goal is important (Locke \& Latham, 2002). A person's goal commitment mediates the effect his/her self-efficacy has on their learning performance (Chu \& Peng, 2009). Moreover, entrepreneurial passion has the positive effects on new venture growth through the mediation of goal commitment (Drnovsek, Cardon, \& Murnieks, 2009). According to the literature of organizational behavior, employees who are committed to specific challenging goals outperform those who either do not have goals or have only a weak commitment to them (Locke \& Latham, 2006). Goal setting has the advantage of helping the entrepreneur direct his/her efforts in a more focused manner (Callanan, \& Zimmerman, 2016).

Moreover, once the goals are in place, complementary behaviors and attitudes that reinforce them will occur naturally (Locke \& Latham, 2006). Goals and self-efficacy have been found to have direct effects on venture growth and to mediate the effects of passion, tenacity, and new resource skills on subsequent growth (Baum \& Locke, 2004).

Goal commitment, on the other hand, has been studies and verified to be important at different stages of the entrepreneurial process (Przepiorka, 2016). Empirical studies have found out that entrepreneurial role models (i.e., parents) not only predicted entrepreneurial intentions (Geldhof et al., 2014; Schmitt-Rodermund, 2004), but also the development of entrepreneurship (Bosma et al, 2012; McClelland, 1961). Considering all of the above, the following hypotheses were proposed.

H3: Students' GC has a direct effect on their CEI. $(\mathrm{M} \rightarrow \mathrm{Y}, \mathrm{b})$.

H4: Students' GC mediates effect their CESE has on their CEI $\left(X, M \rightarrow Y, a^{*} b, c^{\prime}\right)$.

H5: The presence or no presence of ERMs (PERMs/NERMs) has a significant categorical mediation effect on the relationship among model constructs.

Figure 1 showed the research model and illustrated the relationship among the 4 hypotheses.

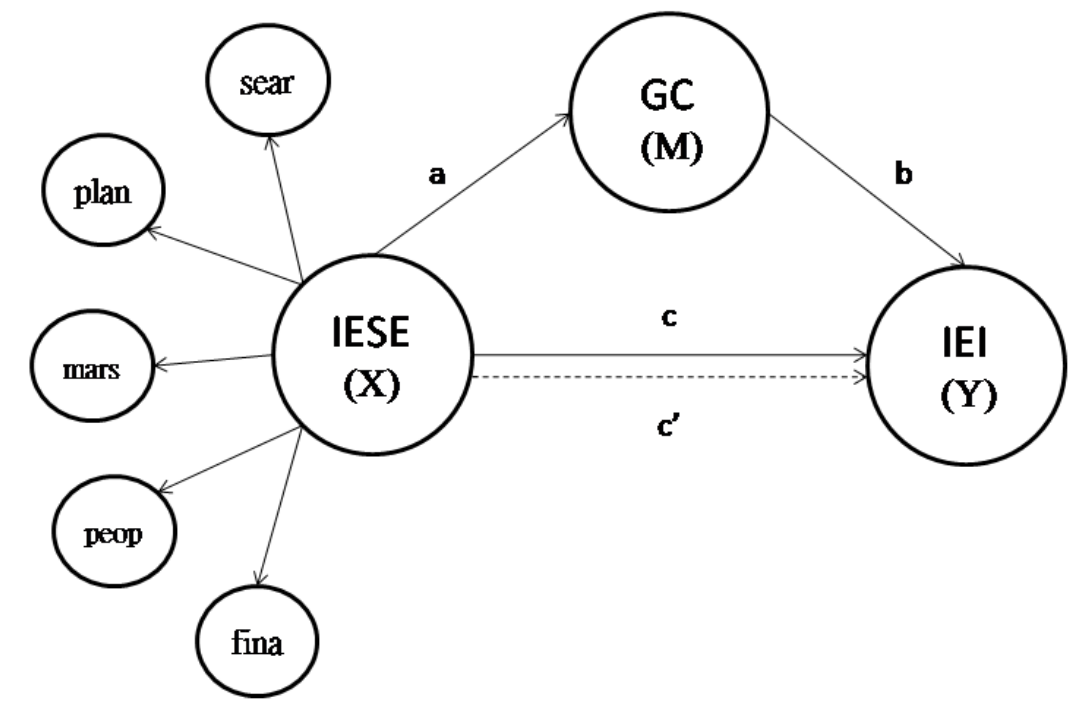

Figure 1. Research Model

\section{METHODOLOGY OF RESEARCH}

\section{Samples and Procedure}

All participants were undergraduate students from the colleges and universities in Taiwan. Armstrong and Overton (1977) suggested that researchers could divide the questionnaires into two groups, the first two weeks 
$(n=130)$ and the last two weeks $(n=149)$ according to the survey interval, to test the differences of constructors. Therefore, this study conducts the t-test (CESE $t=0.244, p>.05$; GC $t=1.270, p>.05$; CEI $t=0.804, p>.05)(p>0.05)$ to ensure that the samples does not suffer from bias.

This study is part and parcel of the cyber entrepreneurship education program, so the participants were asked to first write down one e-commerce- or entrepreneurship-related course they had taken before they proceeded to complete the questionnaire. Of the 279 viable samples, 146 students had entrepreneurial role models (PERMs) and 133 students had none (NERMs); $55.9 \%$ were males and $44.1 \%$ were females; $52.3 \%$ majored in business (or information) management, $29.8 \%$ majored in science, engineering and technology, $7.5 \%$ majored in education, $6.1 \%$ majored in medicine, and $4.3 \%$ majored in others subjects. The majority (82\%) undertook in the businessmanagement and science/engineering/technology (STEM) majors (see Table 1).

Table 1. Number and Percentage of Students in Each Major

\begin{tabular}{|c|c|c|c|c|}
\hline \multirow[b]{2}{*}{ Major } & \multicolumn{2}{|c|}{ Population } & \multicolumn{2}{|c|}{ Sample } \\
\hline & Number & Percentage (\%) & Number & Percentage (\%) \\
\hline Science, Engineering and Technology & 327,272 & 36.54 & 83 & 29.75 \\
\hline Business Management & 263,415 & 29.41 & 146 & 52.33 \\
\hline Education & 21,386 & 2.39 & 21 & 7.53 \\
\hline Medicine & 92,437 & 10.32 & 17 & 6.09 \\
\hline Others & 191,234 & 21.35 & 12 & 4.30 \\
\hline Total & 895,744 & 100.00 & 279 & 100.00 \\
\hline
\end{tabular}

\section{Measuring Instruments}

To ensure construct validity, items selected for the measurement of constructs here were mainly adapted from previous studies and slightly modified to fit the context of cyber entrepreneurship. The instruments used to measure CESE, GC, and CEI were as follows:

\section{Cyber-Entrepreneurial Self-Efficacy (CESE)}

Our "Cyber Entrepreneurial Self-Efficacy (CESE) Scale" was adapted from the "Entrepreneurial Self-Efficacy (ESE) Scale" developed by McGee et al. (2009). The items in the measure were pretested by experts associated with the fields of cyber entrepreneurship and entrepreneurship education, and then adjusted to ensure articulacy. The scale contains 18 items divided into five subscales of searching, planning, marshaling, implementing-people, and implementing-financial. It employs a 5-point Likert scale ranging from the choices of "strongly disagree" to "strongly agree". Higher scores signified higher levels of confidence. Sample questions were "Brainstorm (come up with) a new idea for a product or service" (Searching), "Estimate customer demand for a new product or service" (Planning), "Get others to identify with and believe in my vision and plans for a new business" (Marshaling), "Supervise employees" (Implementing-people), and "Organize and maintain the financial records of my business" (Implementing-financial).

\section{Goal Commitment (GC)}

The 4-item scale we used to measure goal commitment was derived from the 4-item model designed by Klein et al. (2001). A 5-point Likert scale was used with choices ranging from "strongly disagree" to "strongly agree". Higher scores signified higher degrees of commitment to the goal. Sample questions were "I am strongly committed to pursuing this goal" and "I think this is a good goal to shoot for".

\section{Cyber-Entrepreneurial Intentions (CEI)}

We compiled our "Cyber-Entrepreneurial Intentions (CEI) Scale" based on the "Entrepreneurial Intentions (EI) Scale" developed by Liñán and Chen (2009). The resultant 6-item 5-point Likert scale offered answer choices ranging from "strongly disagree" to "strongly agree". Higher scores indicated stronger desire for cyber entrepreneurship. Sample questions were "My professional goal is to become a cyber entrepreneur", and "I have a strong ambition to start a cyber enterprise someday".

\section{Data Analysis}

Partial least squares (PLS) testing was performed using the Smart PLS 3.2.6 software (Ringle, Wende, \& Becker, 2015) to examine and analyze the measurement and structural model of the total sample and the two subsamples 
(PERMs and NERMs). First, we tested the validity of all scales with a confirmatory factor analyses (CFAs) to ensure the convergent validity of the tools. Secondly, we applied partial least squares structural equation modeling (PLSSEM), using the Bootstrap resampling technique to resample 5,000 times (Hair, Ringle, \& Sarstedt, 2011) to examine the significance and predictability $\left(R^{2}\right)$ of the path coefficients in the structural model and to determine the goodness of fit with the standardized root mean square residual (SRMR). Lastly, we conducted PLS-MGA (multi-group analysis) to verify the difference in structural model between the PERMs and NERMs. For the differences in path coefficients, we opted for the permutation-based test procedures (Chin \& Dibbern, 2010). The significance of the differences between the estimated parameters of the two, taken into consideration both the equal and different variances, was determined using the parametric approach (Chin, 2010).

\section{RESULTS OF RESEARCH}

\section{Descriptive Statistical Analysis}

Before analyzing the structural models, an independent samples $t$-test was conducted to determine whether significant differences existed between the variables of PERMs and NERMs. As illustrated in Table 2, no significant difference in GC was detected between the two groups; but in CESE and CEI, significant differences were detected. The mean values of both CESE and CEI were significantly higher in PERMs (CESE: $\mathrm{M}=3.494, t=3.421, p<0.01$; CEI: $\mathrm{M}=3.032, t=2.150, p<0.05)$ than in NERMs and Total Students. This finding suggested the significant effect of PERMs on the CESE and CEI of students, which therefore called for the multi-group analysis (MGA) we subsequently performed.

Table 2. Descriptive Statistics for Total Students, PERMs and NERMs

\begin{tabular}{|c|c|c|c|c|c|c|c|c|}
\hline \multirow[t]{2}{*}{ Contracts } & \multicolumn{2}{|c|}{$\begin{array}{l}\text { Total Students } \\
\quad(n=279)\end{array}$} & \multicolumn{2}{|c|}{$\begin{array}{c}\text { PERMs } \\
(n=146)\end{array}$} & \multicolumn{2}{|c|}{$\begin{array}{c}\text { NERMs } \\
(n=133)\end{array}$} & \multicolumn{2}{|c|}{$\begin{array}{c}\text { Significance of } \\
\text { difference between } \\
\text { PERMs and NERMs }\end{array}$} \\
\hline & Mean & $S D$ & Mean & $S D$ & Mean & $S D$ & t-value & sig. \\
\hline CESE $(X)$ & 3.386 & 0.562 & 3.494 & 0.558 & 3.268 & 0.543 & 3.421 & $* *$ \\
\hline GC (M) & 4.096 & 0.445 & 4.125 & 0.439 & 4.064 & 0.452 & 1.145 & $\mathrm{~ns}$ \\
\hline CEI (Y) & 2.943 & 0.722 & 3.032 & 0.760 & 2.847 & 0.668 & 2.150 & * \\
\hline
\end{tabular}

\section{Reliability and Validity of the Scales}

First, we examined the measurement model. The results of PLS analysis revealed that the factor loadings of all measuring instruments were above 0.7 , signifying indicator and construct reliability; the values of composite reliability (CR) all exceeded 0.7, signifying high internal consistency of measures; and the average variance extracted (AVE) values all exceeded the 0.5 benchmark (Hair, Anderson, Babin, \& Black, 2009; Hair, Hult, Ringle, \& Sarstedt, 2014), signifying the convergent validity of our instruments (See Table 3).

Table 4 shows the discriminant validity of each measure. The square roots of the AVE of our constructs (CESE, GC, and CEI) were all greater their correlations with each other (Fornell \& Larcker, 1981); the heterotrait-monotrait (HTMT) values of all instruments were below the more conservative threshold value of 0.85 (Henseler, Ringle, \& Sarstedt, 2015), thus confirming the excellent discriminant validity of the scales. 
Table 3. Composite Reliability of the Scales

\begin{tabular}{|c|c|c|c|c|c|c|c|c|c|c|}
\hline \multicolumn{2}{|c|}{ Construct/Indicator } & \multicolumn{3}{|c|}{ Total Sample; $\mathbf{n}=279$} & \multicolumn{3}{|c|}{ PERMs; $n=146$} & \multicolumn{3}{|c|}{ NERMs; $n=133$} \\
\hline 2nd-order & 1st-order & Loading & CR & AVE & Loading & CR & AVE & Loading & CR & AVE \\
\hline CESE & & & 0.901 & 0.645 & & 0.899 & 0.643 & & 0.895 & 0.631 \\
\hline & search & 0.829 & 0.893 & 0.735 & 0.816 & 0.906 & 0.763 & 0.830 & 0.866 & 0.683 \\
\hline & plan & 0.831 & 0.830 & 0.619 & 0.839 & 0.830 & 0.619 & 0.819 & 0.829 & 0.618 \\
\hline & marsh & 0.823 & 0.843 & 0.641 & 0.822 & 0.861 & 0.674 & 0.817 & 0.815 & 0.595 \\
\hline & people & 0.822 & 0.900 & 0.600 & 0.839 & 0.898 & 0.595 & 0.797 & 0.899 & 0.598 \\
\hline & financial & 0.703 & 0.908 & 0.766 & 0.681 & 0.906 & 0.764 & 0.702 & 0.901 & 0.754 \\
\hline & GC & & 0.853 & 0.593 & & 0.868 & 0.624 & & 0.838 & 0.565 \\
\hline & gc_1 & 0.719 & & & 0.722 & & & 0.707 & & \\
\hline & gc_2 & 0.835 & & & 0.856 & & & 0.813 & & \\
\hline & $g c_{-} 3$ & 0.793 & & & 0.800 & & & 0.799 & & \\
\hline & gc_4 & 0.727 & & & 0.775 & & & 0.678 & & \\
\hline & CEI & & 0.933 & 0.737 & & 0.939 & 0.756 & & 0.925 & 0.711 \\
\hline & cei_1 & 0.869 & & & 0.878 & & & 0.873 & & \\
\hline & cei_2 & 0.811 & & & 0.829 & & & 0.794 & & \\
\hline & cei_3 & 0.872 & & & 0.888 & & & 0.836 & & \\
\hline & cei_4 & 0.898 & & & 0.906 & & & 0.883 & & \\
\hline & cei_5 & 0.840 & & & 0.845 & & & 0.826 & & \\
\hline
\end{tabular}

Notes: PERMs = presence of entrepreneurial role models; NERMs = no entrepreneurial role models; CESE = cyber-entrepreneurial self-efficacy; GC = goal commitment; $\mathrm{CEI}=$ cyber-entrepreneurial intentions. CR: Composite reliability; AVE: Average variance extracted.

Table 4. Discriminant Validity of the Scales

\begin{tabular}{|c|c|c|c|c|c|c|c|c|c|}
\hline \multicolumn{10}{|c|}{ Fornell-Larcker Criterion } \\
\hline & \multicolumn{3}{|c|}{ Total sample; $\mathbf{n}=279$} & \multicolumn{3}{|c|}{ PERMs; $n=146$} & \multicolumn{3}{|c|}{ NERMs; $n=133$} \\
\hline Construct & CESE & GC & CEI & CESE & GC & CEI & CESE & GC & CEI \\
\hline CESE & 0.803 & & & 0.803 & & & 0.795 & & \\
\hline GC & 0.431 & 0.770 & & 0.445 & 0.790 & & 0.409 & 0.752 & \\
\hline CEI & 0.439 & 0.355 & 0.858 & 0.559 & 0.365 & 0.870 & 0.267 & 0.338 & 0.843 \\
\hline \multicolumn{10}{|c|}{ Heterotrait-Monotrait Ratio (HTMT) } \\
\hline & \multicolumn{3}{|c|}{ Total sample; $\mathbf{n}=\mathbf{2 7 9}$} & \multicolumn{3}{|c|}{ Model; n = 146} & \multicolumn{3}{|c|}{ No-Model; $n=133$} \\
\hline Construct & CESE & GC & CEI & CESE & GC & CEI & CESE & GC & CEI \\
\hline \multicolumn{10}{|l|}{ CESE } \\
\hline GC & 0.521 & & & 0.528 & & & 0.493 & & \\
\hline CEI & 0.493 & 0.413 & & 0.626 & 0.413 & & 0.292 & 0.394 & \\
\hline
\end{tabular}

Notes: Fornelle-Larcker Criterion: Diagonal elements (bold) are the square root of the variance shared between the constructs and their measures (AVE). Off-diagonal elements are the correlations among constructs. For discriminant validity, diagonal elements should be larger than off-diagonal elements. PERMs $=$ presence of entrepreneurial role models; NERMs $=$ no entrepreneurial role models; CESE $=$ cyber-entrepreneurial self-efficacy; $\mathrm{GC}=$ goal commitment; $\mathrm{CEl}=$ cyber - entrepreneurial intentions.

\section{Structural Model and Hypothesis Testing for the Mediation Effects}

\section{Structural model fit}

Next, we examined the structural model before we proceeded to hypotheses testing. Hair et al. (2011) suggested that collinearity could be a potential issue when the variance inflation factor (VIF) value is 5 or above. Our collinearity assessment results showed that the inner VIF values of the total sample and the two subsamples were all lower than 5 (CESE $\rightarrow$ GC $[1.000,1.000,1.000]$; GC $\rightarrow$ CEI $[1.228,1.247,1.200]$; CESE $\rightarrow$ CEI $[1.228,1.247,1.200])$, indicating the absence of collinearity between predictor variables (Hair et al., 2011).

In assessing the structural model fit, the standardized root mean square residual (SRMR) was applied (Henseler et al., 2014). The results showed that the SRMR values of our total and sub- samples were all above than 0.08 (SRMR has a $0-1$ range), and however values as high as 0.08 are deemed acceptable (Total sample, SRMR=0.087; PERMs, SRMR=0.093; NERMs, SRMR=0.099) (Hu \& Bentler, 1999). The causal relationships within latent variables were verified using PLS-SEM; the explanatory power of our study was determined by the use of R-squared $\left(R^{2}\right)($ Pavlou \& Fygenson, 2006). 


\section{Multi-group analysis}

The permutation algorithm was used to carry out the measurement invariance of composite models (MICOM) presented by Henseler, Ringle, and Sarstedt (2016). The purpose of checking measurement invariance is to verify that the factors are indeed measuring the same underlying construct within each group. It is therefore a prerequisite to conducting MGA tests. The results are shown in Table 5. As can be seen, our data corroborated the configural, compositional and scalar invariance; "full measurement invariance" was therefore obtained, signifying the crosssample validity and stability of our scales.

Table 5. Measurement Invariance (MICOM) Tests

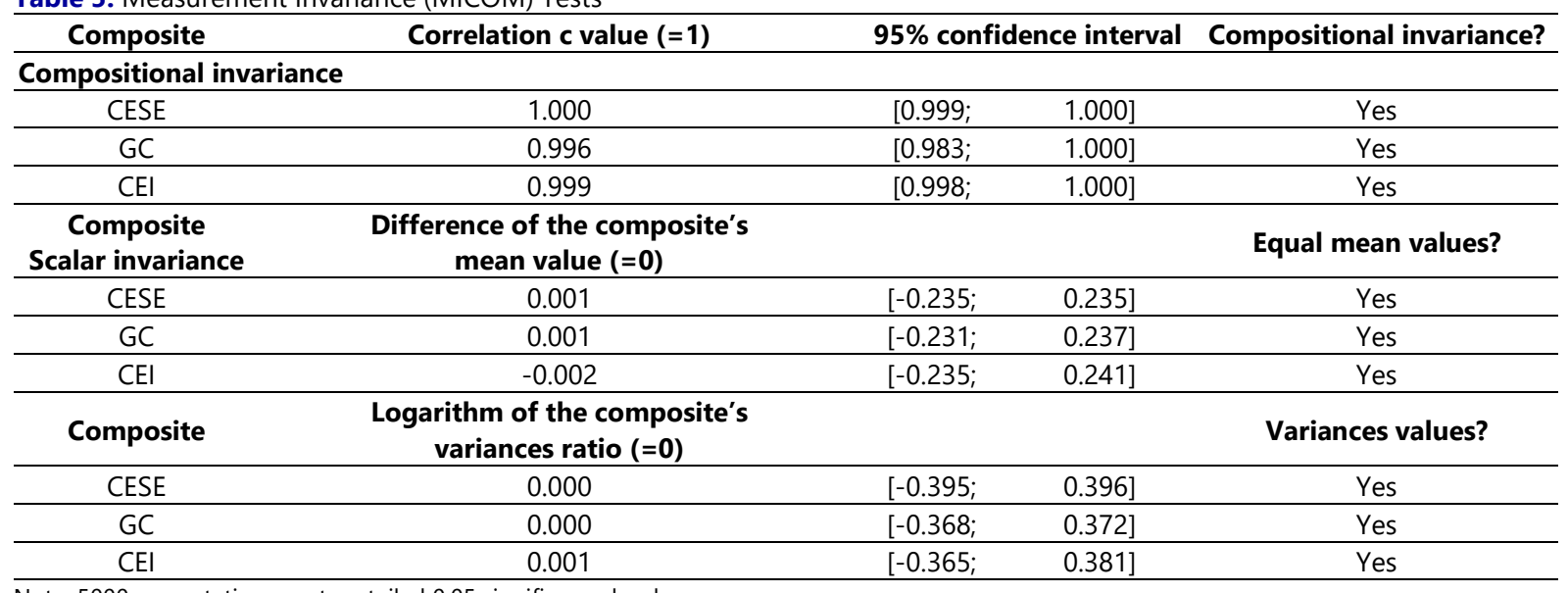

Note: 5000 permutation run; two-tailed 0.05 significance level.

We proceeded to compare the mediating path coefficients of the PERMs and NERMs using the permutation test (5000 permutation runs; two-tailed 0.05 significance level) to determine whether there were significant differences. As shown in Table 6, there were significant differences in the coefficients of the total effects of CESE on CEI ( $p=$ $0.004<0.01)$ and the coefficients of the direct effect of CESE on CEI $(p=0.005<0.01)$ between the two groups; but no significant difference was detected in the coefficients of the direct effects of CESE on GC or GC on CEI, or the indirect effect of GC on the CESE-CEI relationship between the groups. H5 was therefore only partially supported.

Table 6. The Analysis of Mediation

\begin{tabular}{|c|c|c|c|c|c|c|c|c|c|c|c|c|}
\hline \multirow{2}{*}{\multicolumn{2}{|c|}{ Path }} & \multicolumn{2}{|c|}{ Total $(n=279)$} & \multicolumn{3}{|c|}{ PERMs $(n=146)$} & \multicolumn{3}{|c|}{ NERMs $(n=133)$} & \multicolumn{3}{|c|}{ Difference between Coefficient } \\
\hline & & \multirow[t]{2}{*}{ Coeff. } & t-value & \multirow[t]{2}{*}{ Coeff. } & \multicolumn{2}{|c|}{ t-value } & \multirow[t]{2}{*}{ Coeff. } & \multicolumn{2}{|l|}{ t-value } & \multirow[t]{2}{*}{ Diff. } & \multirow[t]{2}{*}{ pHenseler } & \\
\hline Direct Effects & & & & & & & & & & & & \\
\hline $\mathrm{CESE} \rightarrow \mathrm{GC}$ & $a$ & 0.431 & $7.590 * \star \star$ & 0.445 & 5.815 & $* \star \star$ & 0.409 & 4.950 & *** & 0.036 & 0.377 & ns \\
\hline $\mathrm{GC} \rightarrow \mathrm{CEI}$ & $\mathrm{b}$ & 0.203 & $3.215 \quad * *$ & 0.145 & 1.904 & ns & 0.275 & 2.808 & ** & -0.131 & 0.853 & $\mathrm{~ns}$ \\
\hline CESE $\rightarrow$ CEI & $c^{\prime}$ & 0.351 & $5.138 * * *$ & 0.495 & 6.636 & $* * *$ & 0.153 & 1.439 & $\mathrm{~ns}$ & 0.342 & 0.005 & ** \\
\hline \multicolumn{13}{|l|}{ Indirect Effects } \\
\hline $\mathrm{CESE} \rightarrow \mathrm{GC} \rightarrow \mathrm{CEI}$ & $a * b$ & 0.088 & 2.930 ** & 0.064 & 1.724 & ns & 0.113 & 2.469 & * & -0.048 & 0.794 & $\mathrm{~ns}$ \\
\hline Percentile bootstrap & p 95\% Cl & {$[0.034$,} & $0.153]$ & {$[-0.003$,} & $0.142]$ & & {$[0.035$,} & $0.210]$ & & & & \\
\hline \multicolumn{13}{|l|}{ Total Effects } \\
\hline $\mathrm{CESE} \rightarrow \mathrm{CEI}$ & $\begin{array}{c}c= \\
a^{*} b+c^{\prime}\end{array}$ & 0.439 & $7.518 * \star \star$ & 0.560 & 8.873 & $* * *$ & 0.266 & 2.798 & ** & 0.294 & 0.004 & $* *$ \\
\hline \multicolumn{13}{|l|}{ Mediation Effects } \\
\hline \multicolumn{13}{|c|}{ VAF (Variance account of) } \\
\hline$a * b /\left(a * b+c^{\prime}\right)^{\star} 1$ & $00 \%$ & $20.05 \%$ & & $11.45 \%$ & & & $42.48 \%$ & & & & & \\
\hline
\end{tabular}

Parameter estimation was conducted for the comparison of the two groups. The standard errors and parameters of the resamples were used to calculate the $t$-values to determine whether there were significant differences in the coefficients of the paths between the groups. This was done in case our data were distributed normally and/or the variances of the two groups were not too different from each other ( $t$ Param $\{E V\})$. A Welch-Satterthwait test $t$ Param $\{\mathrm{NEV}\}$ was also done in case the variances between the two were very different (Sarstedt, Henseler, \& Ringle, 2011). The results of the two tests were similar: Indirect Effects CESE $\rightarrow$ CEI $-t$ Param $\{E V\}=2.676(p<0.01)$, $t$ Param $\{\mathrm{NEV}\}=2.639(p<0.01)$; Total effects CESE $\rightarrow$ CEI $-t$ Param $\{E V\}=2.628(p<0.01), t$ Param $\{\mathrm{NEV}\}=2.586(p$ 
$<0.05)$. The R-squared values were as follows: PERMs - CESE $\rightarrow$ GC $(19.8 \%)$, CESE $\rightarrow$ GC $\rightarrow$ CEI $(33.0 \%)$; NERMs $\mathrm{CESE} \rightarrow \mathrm{GC}(16.7 \%), \mathrm{CESE} \rightarrow \mathrm{GC} \rightarrow \mathrm{CEI}(13.4 \%)$. Significant differences were detected in all (See Figure 2).

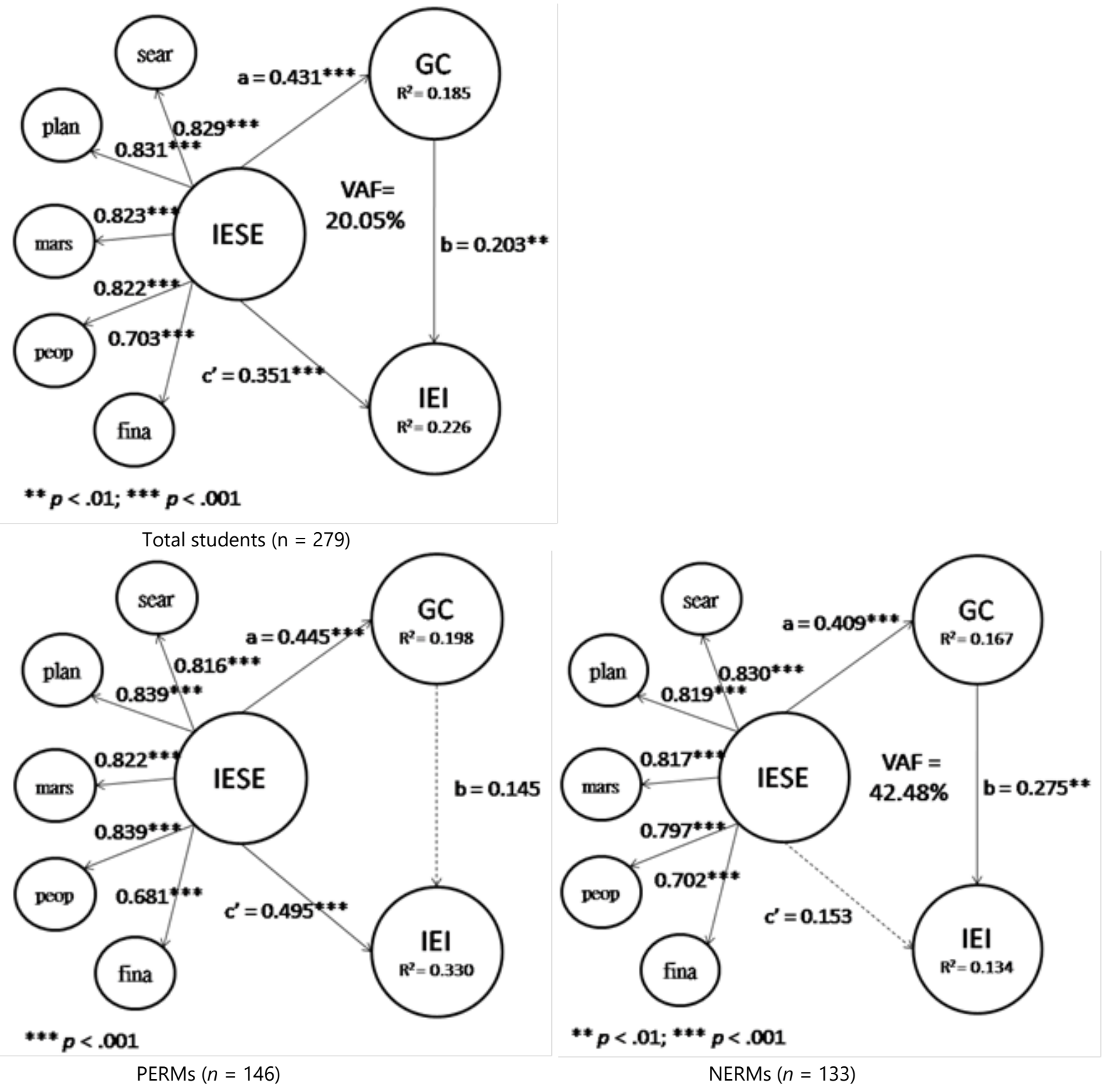

Figure 2. Results of Structural Model Analysis

\section{Hypotheses testing for the mediation effects}

Hypothesis 4 investigated the mediating role of goal commitment (GC), with student's CESE as the independent variable $(\mathrm{X})$, CEI as the dependent variable $(\mathrm{Y})$, and GC as the mediator variable $(\mathrm{M})$. The mediating effects of PERMs and NERMs were analyzed using the multi-group analysis (MGA). Sequential testing was conducted according to the suggestions offered by Hair et al. (2014) on mediation analysis: (1) X significantly predicts $Y$; (2) X significantly predicts $\mathrm{M}$ and $\mathrm{M}$ significantly predicts $\mathrm{Y}$; (3) $\mathrm{X}$ and $\mathrm{M}$ both significantly predict $\mathrm{Y}$.

We examined the mediation model through the assessment of the variance accounted for (VAF): VAF $>80 \%$ indicated full mediation; $20 \% \leq \mathrm{VAF} \leq 80 \%$ indicated partial mediation; VAF $<20 \%$ indicated no mediation. Data were analyzed with SmartPLS 3.0 to see whether they supported our hypotheses. PLS-MGA was conducted to determine whether there was a significant difference between the path coefficients of the PERMs and NERMs.

The path coefficients, $\mathrm{t}$-statistics, and their significance are shown in Table 6 . According to the data of the total sample $(\mathrm{n}=279)$, CESE $(X)$ positively predicted CEI $(Y)(c=0.439, p<0.001)$, indicating that H1 was supported; 
CESE $(X)$ positively predicted GC $(\mathrm{M})(\mathrm{a}=0.431, p<0.001)$, indicating that $\mathrm{H} 2$ was supported; and GC $(\mathrm{M})$ positively predicted CEI $(Y)(b=0.203, p<0.01)$, indicating that $\mathrm{H} 3$ was also supported. The mediation analysis revealed that the indirect effect of CESE $(X)$ on CEI $(Y)\left(a^{*} b=0.088, p<0.01,95 \%\right.$ CI $\left.[0.034,0.153]\right)$ was smaller than the direct effect of CESE $(X)$ on CEI $(\mathrm{Y})\left(c^{\prime}=0.351, p<0.001\right)$; VAF-value was $0.201(20 \% \leq \mathrm{VAF} \leq 80 \%)$, indicative of partial mediation. This shows that in the causal relationship of CESE (X) and CEI (Y), GC (M) exhibited the effect of partial mediation; $\mathrm{H} 4$ was thereby supported. The results of the hypotheses testing are illustrated in Figure 2. For the effect of students' CESE $(X)$ on their GC $(\mathrm{M})$, the explanatory power was $18.5 \%\left(R^{2}=0.185\right)$; for the effect of students' CESE $(X)$ on their CEI $(Y)$ via the mediation of their GC $(\mathrm{M})$, the explanatory power was $22.62 \%\left(R^{2}=0.226\right)$.

According to the data of the PERMs ( $\mathrm{n}=146)$, CESE $(X)$ positively predicted CEI $(\mathrm{Y})(\mathrm{c}=0.560, p<0.001)$, indicating that $\mathrm{H} 1$ was supported; CESE $(\mathrm{X})$ positively predicted $\mathrm{GC}(\mathrm{M})(\mathrm{a}=0.445, p<0.001)$, indicating that $\mathrm{H} 2$ was also supported; GC (M), however, failed to significantly predict CEI (Y) (b=0.145, $p>0.05), \mathrm{H} 3$ was therefore not supported. Because $M$ failed to significantly predict $Y$, our model did not fit the sequence of mediation analysis proposed by Hair et al. (2014); therefore there was no mediation, and H4 was not supported (See Figure 2).

According to the data of the NERMs $(n=133)$, CESE $(X)$ positively predicted CEI $(Y)(c=0.266, p<0.01)$, indicating that H1 was supported; CESE (X) positively predicted GC (M) $(\mathrm{a}=0.409, p<0.001$, indicating that $\mathrm{H} 2$ was supported; and GC (M) positively predicted CEI $(\mathrm{Y})(\mathrm{b}=0.275, p<0.01)$, indicating that $\mathrm{H} 3$ was also supported. The mediation analysis revealed that the indirect effect of CESE $(X)$ on CEI $(Y)\left(a^{*} b=0.113, p<0.05,95 \%\right.$ CI [0.035, $0.210])$ was smaller than the direct effect of CESE $(X)$ on CEI $(Y)\left(c^{\prime}=0.153, p>0.05\right)$; VAF-value was $0.425(20 \% \leq$ VAF $\leq 80 \%$ ), indicative of partial mediation. This shows that in the causal relationship of CESE (X) and CEI (Y), GC (M) exhibited the effect of partial mediation; H4 was thereby supported. For the effect of students' CESE (X) on their GC (M), the explanatory power was $16.7 \%\left(R^{2}=0.167\right)$; for the effect of students' CESE $(\mathrm{X})$ on their CEI (Y) via the mediation of their GC $(\mathrm{M})$, the explanatory power was $13.4 \%\left(R^{2}=0.134\right)$ (See Figure 2$)$.

\section{DISCUSSION AND IMPLICATIONS}

The present study investigated the mediation effect of GC on the relationship between CESE and CEI in the context of undergraduate entrepreneurship education. We hope to add to the literature of cyber entrepreneurship education and contribute to the further development of this field. The discussion and implications of our study are as follows.

\section{Cyber-entrepreneurial Self-efficacy has a Direct Positive Effect on Cyber-entrepreneurial Intentions}

The results of the analyses revealed that students' CESE has a direct positive effect on their CEI in the context of cyber entrepreneurship education. Such finding is correspondent with the results of previous research (Barbosa et al., 2007; BarNir et al., 2011; Carr \& Sequeira, 2007; Kickul et al., 2009; Liñán, 2008; Piperopoulos \& Dimov, 2015; Sesen, 2013; Trevelyan, 2011; Zhao et al., 2005). As social cognitive theory claims, no mechanism of personal agency is more central or pervasive than beliefs of self-efficacy (Bandura, 1989). Any factor that may serve as a guide or a motivator is rooted in the core belief that one's actions can lead to desired effects; otherwise, one would have little or no incentive to act or persevere in the face of difficulties (Bandura, 2002). Studies have found that when subjected to equally painful events, those who are led to believe that they have personal control over the events display lower autonomic arousal and less performance impairment than those who believe the opposite (Geer, Davison, \& Gatchel, 1970; Glass et al., 1973). It is therefore important for teachers and researchers of cyber entrepreneurship education to find out how to enhance CESE in students.

\section{Cyber-entrepreneurial Self-efficacy has a Direct Positive Effect on Goal Commitment}

The results of our analyses indicated that students' CESE has a direct positive effect on their GC, which conforms to the findings of previous studies (Baum \& Locke, 2004; Locke et al., 1984; Locke \& Latham, 2002, 2006; $\mathrm{Wu}, 2002$ ). Bouffard-Bouchard (1990) experimentally induced high and low self-efficacy perceptions in college students with equivalent knowledge and experience in a performance domain, and found out that students with fictitiously induced high self-efficacy set higher goals for themselves, used more efficient problem-solving strategies, and achieved higher intellectual performances than did students with induced low self-efficacy. This proved the effect of perceived self-efficacy on goal setting and aspiration (Bandura \& Locke, 2003; Geldhof et al., 2014; Wood \& Bandura, 1989). Our finding is consistent with the belief in social cognitive theory that ESE is an important factor that improves GC (Bandura \& Locke, 2003; Lock \& Latham, 2002). 


\section{The Mediation Effect of Goal Commitment}

People are aspiring and proactive beings, who motivate and guide themselves by setting personal goals and performance standards, and then invest energy and resources to achieve them (Bandura \& Locke, 2003). Przepiorka (2016) identified the differences between entrepreneurs and non-entrepreneurs with respect to goal-commitment (effort, persistence, goal satisfaction) and found out that entrepreneurs with greater goal-commitment (who put in more effort and were more persistent and satisfied with their goals) during the prelaunch phase of the entrepreneurial process had greater intention to succeed.

Other studies have also found that GC has an indirect effect between self-efficacy and learning performance (Chu \& Peng, 2009). In the current study, partial mediation effect of GC was observed between the CESE and CEI of Total Students and NERMs; furthermore, such effect was greater in NERMs than in Total Students. These results are in accordance with the findings of earlier research (Geldhof et al., 2014; Schmitt-Rodermund, 2004).

\section{Comparison of Categorical Effects of PERMs and NERMs}

Role models have long been suggested to have a profound influence on career decisions (Krumboltz, Mitchell, \& Jones, 1976). ERMs have been shown to enhance ESE and EI (Boyd \& Vozikis, 1994; Fayolle, Gailly, \& LassasClerc, 2006). In the present study, we found that the presence of entrepreneurial role models made a significant difference to the effect of students' CESE on their CEIs, but not so much to the relationships between their CESE and GC and their GC and CEI. Interestingly, the partial mediation effect of GC was only found between the CESE and CEIs of the NERMs and not those of the PERMs. One probable explanation is that ERMs lead by example, so that in their presence, the students can foresee their own future as an internet entrepreneur fairly clearly and know fairly well what such a career entails through their observations of the ERMs.

Consequently, the degree of such students' GC cannot have as much impact on their CEIs as the GC of NERMs would on theirs. Without the presence of ERMs, the NERMs will probably need a much higher degree of GC in order to have the courage and motivation to generate a genuine CEI. Fayolle et al. (2006) have stated that EI becomes stronger when self-efficacy is enhanced by the presence of ERMs. St-Jean and Mathieu (2015), however, observed that mentoring appears to have a direct negative effect on the intension (to stay in the profession) of novice entrepreneurs; and suggested that mentoring should come earlier in the entrepreneurial process.

Our study seems to support their claims. In terms education, Fayolle et al. (2006) found that the entrepreneurship education programs they tested had a significant impact on the EI of the students. Piperopoulos and Dimov (2015) discovered that among the students taking theoretically-oriented entrepreneurship courses, higher self-efficacy is associated with lower EIs; and among the ones taking practically-oriented entrepreneurship courses, higher self-efficacy is associated with higher EIs. The findings of the current study seem to suggest that the students with PERMs developed more ambitious EIs under the positive influence of their ERMs. For those with NERMs, such EIs may need to be developed more indirectly.

\section{CONCLUSION}

Our research aims to integrate the concepts of social cognition theory and goal-setting theory in an investigation of the effects of CESE and GC on CEIs in the context of undergraduate entrepreneurship education. The results showed that students' CESE has a positive effect on their GC and CEIs individually, and that their GC also has a positive effect on their CEIs. However, we found that GC only has a partial mediation effect between CESE and CEIs in NERMs but not in PERMs. These results have important implications for the practice and research of higher entrepreneurship education. It means that cyber-entrepreneurship educators and practitioners will be able have a better understanding of the students' CESE through their levels of GC, and come up with better methods or designs for the entrepreneurial curricula that will better promote students' CEIs. Our findings also suggest that when designing the curriculum, entrepreneurship educators should take into consideration the different effects the presence/absence of ERMs might have on the CEIs of students.

Based on the findings of prior research and this study, we propose the following recommendations for schools that offer entrepreneurship education: (1) invite entrepreneurs to serve as mentors/coaches for university students of NERMs, because they could learn the practical cyber entrepreneurship from the interaction with mentors or coaches to cultivate CESE and GC. Moreover, media role models and mentoring are proved to effectively motivate and guided students by foresight of goals (risk control), not just by hindsight of shortfalls (fear of risk or failure). (2) offer innovative interdisciplinary courses or integrated curricula (e.g. The remote role model-theme case study) to integrate the knowledge and practice. (3) establish open-loop university (Cheng, 2016) to allow and encourage potential/aspiring entrepreneurs or students to return to school whenever they desire or feel the need to. (4) create a virtual community with entrepreneurship and innovative atmosphere for potential/aspiring entrepreneurs and experienced ones to continually enhance their CESE and GC by exchanging their knowledge and experiences. (5) 
bring all courses together on a common "learning and application platform" that is fully linked and collaborative with external networks such as those of the government agencies and business organizations. Such platform can help students form a clearer concept of entrepreneurial career intentions, and enhance their CESE and GC before they reach their entrepreneurial goals.

Although we strove to conduct the entire research in the most rigorous manner, some limitations and flaws nevertheless existed; we hereby acknowledge them. First, in terms of the participants, we have surveyed only the undergraduate students in Taiwan majored mostly in business management or STEM. Therefore, the generalizability of our results might be somewhat limited. Secondly, in terms of the variables, even though we have proven that students' GC partially mediates the relationship between their CESE and CEIs, the total variance explained was low. This means that besides CESE and GC, there may be other factors such as perceived collective efficacy (Prussia \& Kinicki, 1996) affecting the level of students' CEIs. In light of the aforementioned limitations, we suggest that future research may survey students from more diverse academic backgrounds and ethnicity, and in different stages of learning to improve generalizability. Future researchers may also want to include more variables in their study to more extensively explore the factors influencing students' CEIs.

\section{ACKNOWLEDGEMENT}

This research is partially supported by the Ministry of Science and Technology (National Science Council), Taiwan, R.O.C., under two project grants MOST 103-2511-S-018-013-MY2 and MOST 105-2511-S-018 -012 -MY3.

\section{REFERENCES}

Anderson, R., Thier, M., \& Pitts, C. (2017). Interpersonal and intrapersonal skill assessment alternatives: Selfreports, situational-judgment tests, and discrete-choice experiments. Learning and Individual Differences, 53, 47-60. https:// doi.org/10.1016/j.lindif.2016.10.017

Arenius, P., \& Minniti, M. (2005). Perceptual variables and nascent entrepreneurship. Small Business Economics, 24(3), 233-247. https:// doi.org/10.1007/s11187-005-1984-x

Armstrong, J. S., \& Overton, T. S. (1977). Estimating nonresponse bias in mail surveys. Journal of Marketing Research, 14(3), 396-402. https:/ / doi.org/10.2307/3150783

Bandura, A. (1989). Human agency in social cognitive theory. American Psychologist, 44(9), 1175-1184. https:/ / doi.org/10.1037/0003-066X.44.9.1175

Bandura, A. (1997). Self-efficacy: The exercise of control. New York: Freeman.

Bandura, A. (2002). Social cognitive theory in cultural context. Journal of Applied Psychology: An International Review, 51(2), 269-290. https:/ / doi.org/10.1111/1464-0597.00092

Bandura, A., \& Locke, E. A. (2003). Negative self-efficacy and goal effects revisited. Journal of Applied Psychology, 88(1), 87-99. http:/ / dx.doi.org/10.1037/0021-9010.88.1.87

Barbosa, S., Gerhardt, M., \& Kickul, J. (2007). The role of cognitive style and risk preference on entrepreneurial selfefficacy and entrepreneurial intentions. Journal of Leadership $\mathcal{E}$ Organizational Studies, 13(4), 86-104. https:/ / doi.org/10.1177/10717919070130041001

BarNir, A., Watson, W. E., \& Hutchins, H. M. (2011). Mediation and moderated mediation in the relationship among role models, self-efficacy, entrepreneurial career intention, and gender. Journal of Applied Social Psychology, 41(2), 270-297. https:/ / doi.org/10.1111/j.1559-1816.2010.00713.x

Baron, R. A. (2004). The cognitive perspective: A valuable tool for answering entrepreneurship's basic "why" questions. Journal of Business Venturing, 19(2), 221-239. https:/ / doi.org/10.1016/S0883-9026(03)00008-9

Baum, J. R., \& Locke, E. A. (2004). The relationship of entrepreneurial traits, skill, and motivation to subsequent venture growth. Journal of Applied Psychology, 89(4), 587-598. https:// doi.org/10.1037/0021-9010.89.4.587

Betz, N. E., \& Hackett, G. (1997). Applications of self-efficacy theory to the career assessment of women. Journal of Career Assessment, 5, 383-402. https:/ / doi.org/10.1177/106907279700500402

Bosma, N., Hessels, J., Schutjens, V., Van Praag, M., \& Verheul, I. (2012). Entrepreneurship and role models. Journal of Economic Psychology, 33(2), 410-424. https://doi.org/10.1016/j.joep.2011.03.004

Bouffard-Bouchard, T. (1990). Influence of self-efficacy on performance in a cognitive task. The Journal of Social Psychology, 130(3), 353-363. https:/ / doi.org/10.1080/00224545.1990.9924591

Boyd, N. G., \& Vozikis, G. S. (1994). The influence of self-efficacy on the development of entrepreneurial intentions and actions. Entrepreneurship Theory and Practice, 18, 63-77. https:/ / doi.org/10.1177/104225879401800404 
Bullough, A., \& Renko, M. (2013). Entrepreneurial resilience during challenging times. Business Horizons, 56(3), $343-$ 350. https:/ / doi.org/10.1016/j.bushor.2013.01.001

Callanan, G. A., \& Zimmerman, M. (2016). To be or not to be an entrepreneur applying a normative model to career decisions. Journal of Career Development, 43(5) 1-15. https:/ / doi.org/10.1177/0894845316633525

Carr, J. C., \& Sequeira, J. M. (2007). Prior family business exposure as international influence and entrepreneurial intent: A theory of planned behavior approach. Journal of Business Research, 60(10), 1090-1098. https:// doi.org/10.1016/j.jbusres.2006.12.016

Cheng, Y. P. (2016). Reimaging University Education: The Shifting Learning Ecosystems in Stanford 2025. Journal of Education Research, 266, 96-112.

Chin, W. W. (2010). How to write up and report PLS analyses. In V. Esposito Vinzi, W. W. Chin, J. Henseler, \& H. Wang (Eds.), Handbook of partial least squares: Concepts, methods and applications (pp. 655-690). Berlin, Germany: Springer-Verlag.

Chin, W. W., \& Dibbern, J. (2010). An introduction to a permutation based procedure for multi-group PLS analysis: Results of tests of differences on simulated data and a cross cultural analysis of the sourcing of information system services between Germany and the USA. In V. Esposito Vinzi, W. W. Chin, J. Henseler, \& H. Wang (Eds.), Handbook of partial least squares: Concepts, methods and applications (pp. 171-193). Berlin, Germany: Springer-Verlag.

Chu, T. H., \& Peng, H. L. (2009). Improving technology-mediated learning effectiveness: An investigation of psychological learning process and collaborative learning performance. Journal of Information Management, 16(1), 135-162.

De Clercq, D., Menzies, T. V., Diochon, M., \& Gasse, Y. (2009). Explaining nascent entrepreneurs' goal commitment: An exploratory study. Journal of Small Business and Entrepreneurship, 22(2), 123-139. https:/ / doi.org/10.1080/08276331.2009.10593446

Drnovsek, M., Cardon, M. S., \& Patel, P. C. (2016). Direct and indirect effects of passion on growing technology ventures. Strategic Entrepreneurship Journal, 10(2), 194-213. https:/ / doi.org/10.1002/sej.1213

Edwards-Schachter, M., García-Granero, A., Sánchez-Barrioluengo, M., Quesada-Pineda, H., \& Amara, N. (2015). Disentangling competences: Interrelationships on creativity, innovation and entrepreneurship. Thinking Skills and Creativity, 16, 27-39. https:/ / doi.org/10.1016/j.tsc.2014.11.006

eMarketer (2014). Worldwide ecommerce Sales to increase nearly $20 \%$ in 2014 . Retrieved from http:/ / www.emarketer.com/ Article/Worldwide-Ecommerce-Sales-Increase-Nearly-20-2014/1011039

Fayolle, A., Gailly, B., \& Lassas-Cierc, N. (2006). Assessing the impact of entrepreneurship education programmes: A new methodology. Journal of Industrial Training, 30(9), 701-720. https:/ / doi.org/10.1108/03090590610715022

Fornell, C., \& Larcker, D. F. (1981). Evaluating structural equation models with unobervables and measurement error. Journal of Marketing Research, 18(1), 39-50. https:/ / doi.org/10.2307/3151312

Gattie, D. K., Kellam, N. K., Schramski, J. R., \& Walther, J. (2011). Engineering education as a complex system. European Journal of Engineering Education, 36(6), 521-535. https:/ / doi.org/10.1080/03043797.2011.622038

Geer, J. H., Davison, G. C., \& Gatchel, R. I. (1970). Reduction of stress in humans through nonveridical perceived control of aversive stimulation. Journal of Personality and Social Psychology, 16(4), 731-738. https:/ / doi.org/10.1037/h0030014

Geldhof, G. J., Weiner, M., Agans, J. P., Mueller, M. K., \& Lerner, R. M. (2014). Understanding entrepreneurial intent in late adolescence: The role of intentional self-regulation and innovation. Journal of Youth and Adolescence, 43(1), 81-91. https:/ / doi.org/10.1007/s10964-013-9930-8

Glass, D. C., Singer, J. E., Leonard, H. S., Krantz, D., Cohen, S., \& Cummings, H. (1973). Perceived control of aversive stimulation and the reduction of stress responsesl. Journal of Personality, 41(4), 577-595. https:/ / doi.org/10.1111/j.1467-6494.1973.tb00112.x

Global Entrepreneurship Research Association (2018). GEM GLOBAL REPORT 2017/18. Retrieved from http://gemconsortium.org/report

Gundry, L. K., Ofstein, L. F., \& Kickul, J. R. (2014). Seeing around corners: How creativity skills in entrepreneurship education influence innovation in business. The International Journal of Management Education, 12(3), 529-538. https://doi.org/10.1016/j.ijme.2014.03.002

Hair, J. F., Anderson, R. E., Tatham, R. L., \& Black, W. C. (2009). Multivariate Data Analysis (7th ed.). Englewood Cliffs, NJ: Prentice Hall. 
Hair, J. F., Hult, G. T. M., Ringle, C. M., \& Sarstedt, M. (2014). A primer on partial least squares structural equation modeling (PLS-SEM). Thousand Oaks, CA: Sage.

Hair, J. F., Ringle, C. M., \& Sarstedt, M. (2011). PLS-SEM: Indeed a silver bullet. Journal of Marketing Theory and Practice, 18(2), 139-152. https:/ / doi.org/10.2753/MTP1069-6679190202

Henseler, J., Dijkstra, T. K., Sarstedt, M., Ringle, C. M., Diamantopoulos, A., Straub, D. W., Ketchen, D. J. Jr, Hair, J. F., Hult, G. T. M. \& Calantone, R. J. (2014). Common beliefs and reality about PLS: Comments on Rönkkö \& Evermann (2013). Organizational Research Methods, 17(2), https:/ / doi.org/10.1177/1094428114526928

Henseler, J., Ringle, C. M., \& Sarstedt, M. (2015). A new criterion for assessing discriminant validity in variancebased structural equation modeling. Journal of the Academy of Marketing Science, 43(1), 115-135. https:/ / doi.org/10.1007/s11747-014-0403-8

Henseler, J., Ringle, C. M., \& Sarstedt, M. (2016). Testing measurement invariance of composites using partial least squares. International Marketing Review, 33(3), 405-431. https:/ / doi.org/10.1108/IMR-09-2014-0304

Hu, L. T., \& Bentler, P. M. (1999). Cutoff criteria for fit indexes in covariance structure analysis: Conventional criteria versus new alternatives. Structural Equation Modeling: A multidisciplinary Journal, 6(1), 1-55. https://doi.org/10.1080/10705519909540118

Huang, K. P. (2017). Entrepreneurial Education: The Effect of Entrepreneurial Political Skill on Social Network, Tacit Knowledge, and Innovation Capability. Eurasia Journal of Mathematics, Science and Technology Education, 13(8), 5061-5072. https:/ / doi.org/10.12973/ eurasia.2017.00982a

Jiang, H., Xiong, W., \& Cao, Y. (2017). Research on the Mechanism of Entrepreneurial Education Quality, Entrepreneurial Self-efficacy and Entrepreneurial Intention in Social Sciences, Engineering and Science Education. Engineering and Science Education. Eurasia Journal of Mathematics, Science $\mathcal{E}$ Technology Education, 13(7), 3709-3721. https:/ / doi.org/10.12973/eurasia.2017.00754a

Kickul, J., Gundry, L. K., Barbosa, S. D., \& Whitcanack, L. (2009). Intuition versus analysis? Testing differential models of cognitive style on entrepreneurial self-efficacy and the new venture creation process. Journal of Entrepreneurship Theory and Practice, 33(2), 439-453. https:/ / doi.org/10.1111/j.1540-6520.2009.00298.x

Klein, H. J., Wesson, M. J., Hollenbeck, J. R., Wright, P. M., \& DeShon, R. P. (2001). The assessment of goal commitment: A measurement model meta-analysis. Organizational Behavior and Human Decision Processes, 85(1), 32-55. https://doi.org/10.1006/obhd.2000.2931

Krumboltz, J., Mitchell, A., \& Jones, G. (1976). A social learning theory of career selection. The Counseling Psychologist, 6, 71-80. https:/ / doi.org/10.1177/001100007600600117

Lent, R. W., Brown, S. D., \& Hackett, G. (1994). Toward a unifying social cognitive theory of career and academic interest, choice, and performance. Journal of Vocational Behavior, 45(1), 79-122. https://doi.org/10.1006/jvbe.1994.1027

Liñán, F. (2008). Skill and value perceptions: How do they affect entrepreneurial intentions? International Entrepreneurship and Management Journal, 4(3), 257-272. https:/ / doi.org/10.1007/ s11365-008-0093-0

Liñán, F., \& Chen, Y. W. (2009). Development and cross-cultural application of a specific instrument to measure entrepreneurial intentions. Entrepreneurship Theory and Practice, 33(3), 593-617. https:// doi.org/10.1111/j.1540-6520.2009.00318.x

Liñán, F., \& Fayolle, A. (2015). A systematic literature review on entrepreneurial intentions: citation, thematic analyses, and research agenda. International Entrepreneurship and Management Journal, 11(4), 907-933. https:// doi.org/10.1007/s11365-015-0356-5

Liu, C. Y., Wen, C. T., \& Hsieh, R. M. (2011). A survey of entrepreneurship and policy implications in Taiwan: Evidence from global entrepreneurship monitor Data. The 14th Conference on Interdisciplinary and Multifunctional Business Management. Soochow University, Taipei, Taiwan.

Locke, E. A., \& Latham, G. P. (2002). Building a practically useful theory of goal setting and task motivation. American Psychologist, 57(9), 705-717. https:// doi.org/10.1037/0003-066X.57.9.705

Locke, E. A., \& Latham, G. P. (2006). New directions in goal-setting theory. Current Directions in Psychological Science, 15(5), 265-268. https:/ / doi.org/10.1111/j.1467-8721.2006.00449.x

Locke, E. A., Frederick, E., Lee, C., \& Bobko, P. (1984). Effect of self-efficacy, goals, and task strategies on task performance. Journal of Applied Psychology, 69(2), 241-251. https:// doi.org/10.1037/0021-9010.69.2.241

Locke, E. A., Shaw, K. N., Saari, L. M., \& Latham, G. P. (1981). Goal setting and task performance: 1969-1980. Psychological Bulletin, 90(1), 125-152. https://doi.org/10.1037/0033-2909.90.1.125 
Lubart, T. (2008). Connecting learning, individual differences and creativity. Learning and Individual Differences, 18(4), 361-362. https:/ / doi.org/10.1016/j.lindif.2008.10.001

Matlay, H., \& Westhead, P. (2007). Innovation and collaboration in virtual teams of e-entrepreneurs: Case evidence from the European tourism industry. The International Journal of Entrepreneurship and Innovation, 8(1), 29-36. https:/ / doi.org/10.5367/000000007780007353

McClelland, D. C. (1961). The achieving society. Princeton, NJ: Van Nostrand.

McGee, J. E., Peterson, M., Mueller, S. L., \& Sequeira, J. M. (2009). Entrepreneurial self-efficacy: Refining the measure. Entrepreneurship Theory and Practice, 33(4), 965-988. https://doi.org/10.1111/j.15406520.2009.00304.x

Meyer, J. P., \& Herscovitch, L. (2001). Commitment in the workplace toward a general model, Human Resource Management Review, 11(3), 299-326. https:/ / doi.org/10.1016/S1053-4822(00)00053-X

Meyer, J. P., Becker, T. E., \& Van Dick, R. (2006). Social identities and commitments at work: Toward an integrative model. Journal of organizational behavior, 27(5), 665-683. https:/ / doi.org/10.1002/job.383

Ministry of Economic Affairs (2016). Industrial and Economic Development Blueprint. Retrieved from https:/ / www.contacttaiwan.tw/ main/ docdetail.aspx?uid=505\&pid=42\&docid=142

Ministry of Education (2016). University Course Information (UCOURSE). Retrieved from http:/ / ucourse-

tvc.yuntech.edu.tw/web_nu/search_course.aspx?q=\%BD\%D2\%B5\{\%A6W\%BA\%D9\%20LIKE\%20\%27\%B3 $\%$ D0\% B7 \% 27

Ministry of Education Youth Development Department (2012). Assist youth employment programs. Retrieved from http:/ / www.ey.gov.tw/Upload/RelFile/27/689986/1314c3c7-cc5b-42f9-8a03- 838910e3282.pdf

Muofhe, N. J., \& Du Toit, W. F. (2011). Entrepreneurial education's and entrepreneurial role models' influence on career choice. SA Journal of Human Resource Management, 9(1), Art. \#345, 15-pages. https:/ / doi.org/10.4102/sajhrm.v9i1.345

Obschonka, M., Silbereisen, R. K., \& Schmitt-Rodermund, E. (2011). Successful entrepreneurship as developmental outcome: A path model from a life span perspective of human development. European Psychologist, 16(3), 174-186. https://doi.org/10.1027/1016-9040/a000075

OECD (2011). LEED forum on partnerships and local governance. Handbook no. 5. Partnering for success in fostering graduate. OECD LEED. Retrieved from http://www.oecd.org/cfe/leed/47436168.pdf

Pavlou, P. A., \& Fygenson, M. (2006). Understanding and predicting electronic commerce adoption: An extension of the theory of planned behavior. MIS Quarterly, 30(1), 115-143. https:/ / doi.org/10.2307/25148720

Piperopoulos, P., \& Dimov, D. (2015). Burst bubbles or build steam? Entrepreneurship education, entrepreneurial self-efficacy, and entrepreneurial intentions. Journal of Small Business Management, 53(4), 970-985. https://doi.org/10.1111/jsbm.12116

Prussia, G. E., \& Kinicki, A. J. (1996). A motivational investigation of group effectiveness using social cognitive theory. Journal of Applied Psychology, 81(2), 187-199. https:/ / doi.org/10.1037/0021-9010.81.2.187

Przepiorka, A. (2016). What makes successful entrepreneurs different in temporal and goal-commitment dimensions? Time E Society, 25(1), 40-60. https://doi.org/10.1177/0961463X15577264

Ringle, C. M., Wende, S., \& Becker, J.-M. (2015). SmartPLS 3. Boenningstedt: SmartPLS GmbH. Retrieved from http:/ / www.smartpls.com

Sánchez, J. C. (2011). University training for entrepreneurial competencies: Its impact on intention of venture creation. International Entrepreneurship and Management Journal, 7(2), 239-254. https:/ / doi.org/10.1007/s11365-010-0156-x

Sarstedt, M., Henseler, J., \& Ringle, C. M. (2011). Multigroup analysis in partial least squares (PLS) path modeling: Alternative methods and empirical results. Advances in International Marketing, 22(1), 195-218. https:/ / doi.org/10.1108/S1474-7979(2011)0000022012

Schmitt-Rodermund, E. (2004). Pathways to successful entrepreneurship: Parenting, personality, early entrepreneurial competence, and interests. Journal of Vocational Behavior, 65(3), 498-518. https:/ / doi.org/10.1016/j.jvb.2003.10.007

Sesen, H. (2013). Personality or environment? A comprehensive study on the entrepreneurial intentions of university students. Education+ Training, 55(7), 624-640. https://doi.org/10.1108/ET-05-2012-0059

Shane, S., Locke, E. A., \& Collins, C. J. (2003). Entrepreneurial motivation. Human Resource Management Review, 13(2), 257-279. https:/ / doi.org/10.1016/S1053-4822(03)00017-2 
Shepherd, D. A., Williams, T. A., \& Patzelt, H. (2015). Thinking about entrepreneurial decision making: Review and research agenda. Journal of Management, 41(1), 11-46. https:/ / doi.org/10.1177/0149206314541153

St-Jean, É., \& Mathieu, C. (2015). Developing attitudes toward an entrepreneurial career through mentoring: The mediating role of entrepreneurial self-efficacy. Journal of Career Development, 42(4), 325-338. https:/ / doi.org/10.1177/0894845314568190

Stokes, D., \& Wilson, N. (2010). Small business management and entrepreneurship (6 $6^{\text {th }}$ ed.). Andover: Cengage Learning EMEA.

TiC 100 (2018). About TiC 100. Retrieved from http:/ / intern.advantech.tw/about/

Trevelyan, R. (2011). Self-regulation and effort in entrepreneurial tasks. International Journal of Entrepreneurial Behavior E Research, 17(1), 39-63. https:/ / doi.org/10.1108/13552551111107507

Vancouver, J. B., Thompson, C. M., \& Williams, A. A. (2001). The changing signs in the relationships among selfefficacy, personal goals, and performance. Journal of Applied Psychology, 86(4), 605-620. https:/ / doi.org/10.1037/0021-9010.86.4.605

Vancouver, J. B., Thompson, C. M., Tischner, E. C., \& Putka, D. J. (2002). Two studies examining the negative effect of self-efficacy on performance. Journal of Applied Psychology, 87(3), 506-513. https:// doi.org/10.1037//00219010.87.3.506

Vanevenhoven, J. (2013). Advances and challenges in entrepreneurship education. Journal of Small Business Management, 51(3), 466-470. https:/ / doi.org/10.1111/jsbm.12043

Wang, Y. S., Lin, S. J., Yeh, C. H., Li, C. R., \& Li, H. T. (2016). What drives students' cyber entrepreneurial intention: The moderating role of disciplinary difference. Thinking Skills and Creativity, 22, 22-35. https:// doi.org/10.1016/j.tsc.2016.08.003

White, S., \& Locke, E. (2000). Problems with the Pygmalion effect and some proposed solutions. Leadership Quarterly, 11,389-415. https:/ / doi.org/10.1016/S1048-9843(00)00046-1

Wood, R., \& Bandura, A. (1989). Social cognitive theory of organizational management. Academy of Management Review, 14(3), 361-384. https:/ / doi.org/10.5465/amr.1989.4279067

$\mathrm{Wu}, \mathrm{W} . \mathrm{H}$. (2002). An empirical study of past performance, goal commitment, computer self-efficacy, and computer performance of computer skill learner-an integration of social cognitive theory and goal-setting theory. Journal of Taiwan Normal University: Science Education, 47(1), 39-54.

Wu, Y. C. J., Kuo, T., \& Shen, J. P. (2013). Exploring social entrepreneurship education from a Web-based pedagogical perspective. Computers in Human Behavior, 29(2), 329-334. https:/ / doi.org/10.1016/j.chb.2012.08.012

Zhao, H., Seibert, C., \& Hills, C. (2005). The mediating role of self-efficacy in the development of entrepreneurial intentions. Journal of Applied Psychology, 90(2), 1265-1272. https:/ / doi.org/10.1037/0021-9010.90.6.1265

\section{http://www.ejmste.com}

